\title{
David Oliver: At last, some political honesty?
}

\author{
David Oliver consultant in geriatrics and acute general medicine
}

Berkshire

I've repeatedly criticised the government and its arm's length bodies for selective use of data on NHS performance, staffing, and funding. ${ }^{12}$ Spin is futile when there are frequent independent reports on the true picture. In May and June 2018, for instance, we've seen a King's Fund report on NHS funding performance and international comparators, ${ }^{3}$ the Centre for Progressive Policy's Diagnosis Critical paper, ${ }^{4}$ the House of Commons Library's own hard hitting, data rich report on NHS performance, ${ }^{5}$ and the Institute for Fiscal Studies' reports on health $^{6}$ and social care ${ }^{7}$ funding.

There's no hiding place from such scrutiny for politicians. The NHS has among the fewest acute beds and clinicians per 1000 among OECD nations; it faces major funding shortfalls, workforce gaps, declining staff morale, recruitment, and retention, and worsening operational performance. Reductions in social care funding have left that sector on the brink of collapse, with people and their families increasingly denied services that were already rationed and restricted. ${ }^{8}$

It's a tribute to the dedication and values of staff in these services that they are still afloat and that, in the British Social Attitudes Survey, the NHS remains the institution the public is most proud of and would prioritise for any additional funding from tax increases-which respondents said that they would willingly pay. ${ }^{9-11}$ Nurses and doctors remain the most trusted of all professionals. Politicians are near the bottom of that league table and undermine the NHS at their electoral peril. Voters want a group to blame and hold to account.

The survey shows that people's view of NHS performance is converging with what the independent data are telling us. ${ }^{912}$ They know that things are getting worse, and their biggest areas of concern are around access, waiting times, funding, and staffing. Add to the mix endless national and local media coverage of problems in the NHS and concerted, persistent lobbying from health think tanks, medical colleges, NHS professional associations, health charities, and unions. Throw into the pot a precarious government, preoccupied by Brexit and fearful of reputational damage over the NHS, and it's a recipe for change. It took too long to reach simmering point.
This pressing realpolitik has emboldened organisations to be more critical of government and gradually more realistic and transparent.

I hope that we've belatedly entered an era of honesty and purposeful action from politicians and national NHS leadership

Last year Simon Stevens, NHS England's chief executive, challenged the government very publicly on the need for urgent, meaningful increases in NHS funding. The initial small, three year uplift in funding from the chancellor was underwhelming and well short of the additional minimum $4 \%$ real terms yearly increase urged by experts at the Health Foundation, King's Fund, Nuffield Trust, and Institute for Fiscal Studies. ${ }^{613}$

Jeremy Hunt, health and social care secretary, has now telegraphed plans to put NHS funding on a longer term sustainable basis, hinting at such levels of funding increase, and he has reportedly fought this corner in the cabinet. ${ }^{10}{ }^{14}$ Prime Minister May has announced that the NHS in England will get an extra $£ 20$ bn a year by 2023 as a 70 th birthday present. ${ }^{15}$ Understandably, conditions and expectations are attached, and Hunt has said that his key priorities include access to mental health services, better performance on cancer, perinatal care, patient safety, and health and social care integration.

The Home Office has just agreed to lift visa restrictions for doctors and nurses from non-EU countries ${ }^{16}$ - timely, with NHS Improvement admitting that one in 11 clinical posts is unfilled ${ }^{17}$ and the NHS's ongoing reliance on staff trained overseas. ${ }^{18}$

We have concrete plans for an extra 1500 medical school places. ${ }^{19}$ Maybe more will be announced. The ongoing green paper review of social care funding and provision is being led personally by the health secretary. ${ }^{20}$ The social care problem is now being acknowledged and given serious consideration-rather than delegated to junior ministers, never-implemented commissions, or ill considered election manifesto promises.

I remain suitably wary, as presenting the new money as a "Brexit dividend" looks like yet more party political spin. ${ }^{15}$ But I hope that we've belatedly entered an era of honesty and purposeful action from politicians and national NHS leadership. Lobbying 
and campaigning can work if enough credible organisations keep going for long enough and the stark facts become hard for politicians to ignore.

Competing interests: See www.bmj.com/about-bmj/freelance-contributors/davidoliver.

Provenance and peer review: Commissioned; not externally peer reviewed.

Follow David on Twitter: @mancunianmedic

1 Oliver D. David Oliver: Lies, damned lies, and the NHS. BMJ 2016:354:i409310.1136/bmj.i4093

2 Oliver D. David Oliver: Time for a truly independent NHS statistics authority. BM 2017;357:j3045. 10.1136/bmj.j3045 28666978

3 Ward D, Chijoko L. Spending on and availability of health care resources: how does the UK compare to other countries? King's Fund. 5 May 2018. https://www.kingsfund.org.uk publications/spending-and-availability-health-care-resources.

4 Centre for Progressive Policy. Diagnosis critical: launching an inquiry into the state of health and social care in England. June 2018. http://progressive-policy.net/wp-content/ uploads/2018/06/Report_Diagnosis-Critical-1.pdf.

5 House of Commons Library. NHS key statistics, May 2018. 21 May 2018. https:// researchbriefings.parliament.uk/ResearchBriefing/Summary/CBP-7281.

6 Johnson P, Kelly E, Lee T, et al. Cost pressures on the NHS will only grow: it needs a long term funding solution, and that is likely to mean substantial tax rises. Institute for Fiscal Studies. 24 May 2018. https://www.ifs.org.uk/publications/12998.

7 Johnson P, Kelly E, Lee T, et al. Securing the future: funding health and social care to the 2030s. Institute for Fiscal Studies. 24 May 2018. https://www.ifs.org.uk/publications/ 12994.

8 Humphries R, Hall P, Charles A, Thorlby R, Holder H. Social care for older people: home truths. King's Fund. 15 Sept 2016. https://www.kingsfund.org.uk/publications/social-careolder-people.
9 Nuffield Trust. Public perceptions of the NHS and social care. 28 Feb 2018. https://www. nuffieldtrust.org.uk/spotlight/public-perceptions-of-the-nhs.

10 Buchan L. Jeremy Hunt says people are willing to pay higher taxes amid NHS funding row. Independent 25 May 2018. https://www.independent.co.uk/news/uk/politics/jeremyhunt-nhs-funding-row-higher-taxes-conservative-healthcare-a8368521.html.

11 Evans $\mathrm{H}$. Does the public see tax rises as the answer to NHS funding pressures? King's Fund. 12 April 2018. https://www.kingsfund.org.uk/publications/does-public-see-tax-risesanswer-nhs-funding-pressures.

12 Robertson R, Appleby J, Evans H. Public satisfaction with the NHS and social care in 2017. 28 Feb 2018. https://www.kingsfund.org.uk/publications/public-satisfaction-nhs2017.

13 Health Foundation, King's Fund, Nuffield Trust. Joint letter to the Prime Minister on NHS funding. 6 June 2018. https://www.health.org.uk/news/joint-letter-prime-minister-nhsfunding.

14 Campbell D. Hammond and Hunt in battle over NHS funding boost. Guardian 10 May 2018. https://www.theguardian.com/society/2018/may/10/hammond-and-hunt-in-battleover-nhs-funding-boost.

15 Triggle N. NHS funding: Theresa May unveils £20bn boost. BBC News 17 June 2018 https://www.bbc.co.uk/news/health-44495598.

16 Rimmer A. Home Office scraps cap on doctors' visas. BMJ 2018;361:k2648. 10.1136/bmj.k2648 29903918

17 Matthews-King A. More than 100000 NHS posts unfilled, reveal "grim" official figures. Independent 21 Feb 2018. https://www.independent.co.uk/news/health/nhs-posts-staffing recruitment-official-figures-healthcare-hospitals-a8221961.html.

18 Public Health England. Facing the facts, shaping the future. 2017. https://bit.ly/2kKUuCL.

19 Mahankali-Rao P. What you should know about the 1500 increase in medical schoo places. Student BMJ 2017;20. http://student.bmj.com/student/view-article.html?id=sbmj. j5166.

20 Conservative Home. Hunt on social care: "I want to be honest about how well we are meeting that litmus test. In truth, not well enough." 20 March 2018. https://www. conservativehome.com/parliament/2018/03/hunt-on-social-care-i-want-to-be-honest-abouthow-well-we-are-meeting-that-litmus-test-in-truth-not-well-enough.html.

Published by the BMJ Publishing Group Limited. For permission to use (where not already granted under a licence) please go to http://group.bmj.com/group/rights-licensing/ permissions 